\title{
Tumour-like lumbar disc herniation
}

\author{
Baogan Peng, Xiaodong Pang
}

Department of Spinal Surgery, General Hospital of Armed Police Force, Beijing, China

\section{Correspondence to}

Professor Baogan Peng, pengbaogan@163.com
To cite: Peng $B$, Pang $X$ BMJ Case Rep Published online: [please include Day Month Year] doi:10.1136/ bcr-2013-009358

\section{DESCRIPTION}

A 49-year-old man was admitted with right lower extremity pain and numbness that had lasted for 1 year. He had also experienced a sudden exacerbation of the symptoms for 10 days before admission. Physical examination revealed a negative straight leg raising sign in both lower extremities, weakness of the extensor hallucis longus and disappeared ankle reflex in his right lower extremity. MRI revealed a tumour-like lesion in the lumbar (L) spinal canal located between the L4-L5 and L5-S1 (L5-sacral 1) disc space levels. The lesion was encased by cystoid adipose tissue which showed high-intensity signal on the T1-weighted and T2-weighted images (figures 1 and 2). The patient underwent right L5 haemilaminectomy. A huge sequestered disc fragment was found in the epidural space, and subsequently was easily extirpated (figure 3, wet weight $30 \mathrm{~g}$ ). An irregular rip was found in the right rear of L4-L5 disc. Further exploration found that L4-L5 disc was completely empty, which indicated that the sequestered disc fragment came from L4-L5 disc herniation. A herniated disc tissue was demonstrated by histological examination. Postoperatively, the patient had complete resolution of his right extremity symptoms over 3 months.

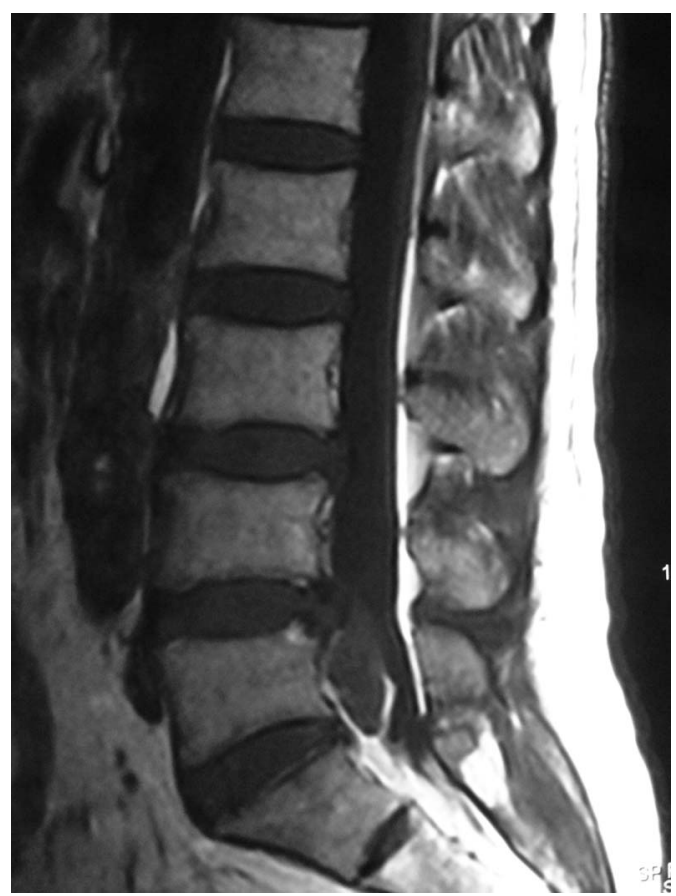

Figure 1 Sagittal T1-weighted MR image of lumbar spine revealed a tumor-like lesion with high-intensity signal in periphery in the lumbar spinal canal.

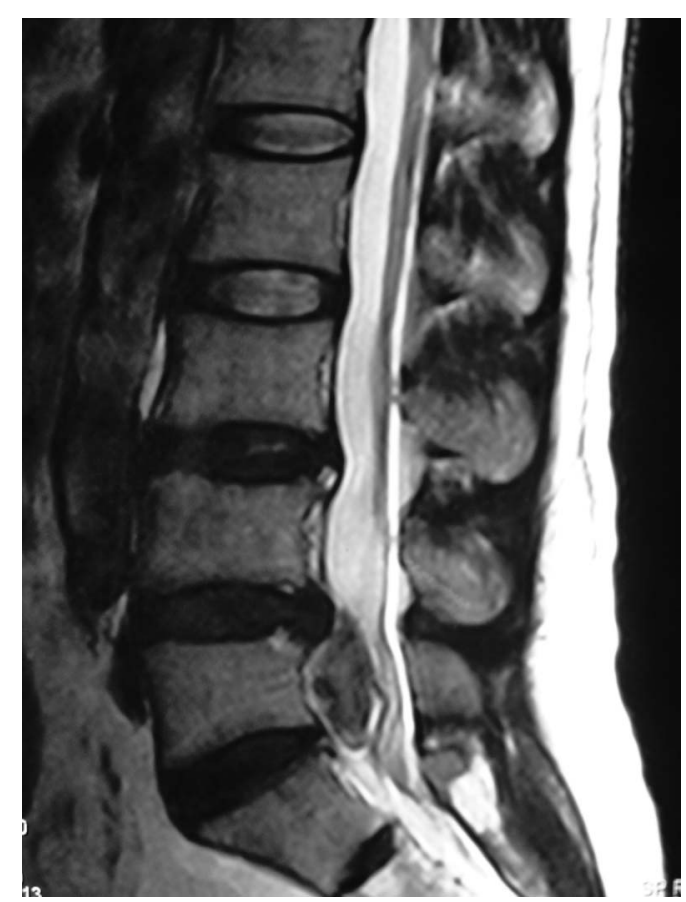

Figure 2 Sigittal T2-weighted MR image showed a heterogeneous tumor-like lesion with high-intensity signal in periphery.

Although the incidence of sequestered disc fragments in the epidural space is common, such a huge sequestered disc fragment located between the L4-L5 and L5-S1 disc space levels is rare, which may result in diagnostic confusion. Before surgery, we cannot diagnose the lesion being an intraspinal tumour or disc herniation. Although MRI remains the best modality of choice to investigate spinal pathologies, however, some disc fragments still can be mistaken for other more common epidural and intradural benign lesions or neoplasms. ${ }^{12}$

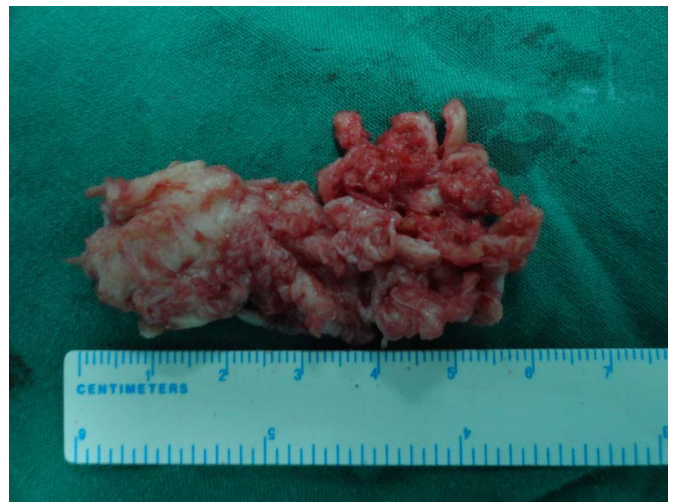

Figure 3 A huge free sequestrated disc fragment was removed. 


\section{Learning points}

- The spinal canal migration of disc fragments simulating intraspinal tumoural space-occupying lesions is rarely found in clinical practice.

- Even with MRI examination, some disc fragments still can be mistaken for other more common epidural and intradural benign lesions or neoplasms.

- A delay in surgical treatment, to perform additional invasive studies, does not seem justified.
Competing interests None.

Patient consent Obtained.

Provenance and peer review Not commissioned; externally peer reviewed.

\section{REFERENCES}

1 Nievas MNC, Hoellerhage HG. Unusual sequestered disc fragments simulating spinal tumors and other space-occupying lesions. J Neurosurg Spine 2009;11:42-8.

2 Aydin MV, Ozel S, Sen 0, et al. Intradural disc mimicking: a spinal tumor lesion. Spinal Cord 2004;42:52-4.

Copyright 2013 BMJ Publishing Group. All rights reserved. For permission to reuse any of this content visit http://group.bmj.com/group/rights-licensing/permissions.

BMJ Case Report Fellows may re-use this article for personal use and teaching without any further permission.

Become a Fellow of BMJ Case Reports today and you can:

- Submit as many cases as you like

- Enjoy fast sympathetic peer review and rapid publication of accepted articles

- Access all the published articles

- Re-use any of the published material for personal use and teaching without further permission

For information on Institutional Fellowships contact consortiasales@bmjgroup.com

Visit casereports.bmj.com for more articles like this and to become a Fellow 